\title{
RELATIONSHIP BETWEEN ATHLETES' VALUES AND MORAL DISENGAGEMENT IN SPORT, AND DIFFERENCES ACROSS GENDER, LEVEL AND YEARS OF INVOLVEMENT
}

\author{
Saulius Šukys ${ }^{1}$, Aušra Janina Jansoniené ${ }^{2}$ \\ Lithuanian Academy of Physical Education ${ }^{I}$, Kaunas, Lithuania \\ Kaunas University of Technology', Kaunas, Lithuania
}

\begin{abstract}
Research background and hypothesis. The research focuses on university athletes' values and moral disengagement in sport. Hypothetically moral and competence values would negatively correlate with moral disengagement in sport. Also, values in sport would differ across gender and sports mastery.

Research aim was to examine the relationship between athletes' values and moral disengagement in sport, and to determine the manifestation of athletes' values and moral disengagement in sport by gender, sports mastery and sports experience.

Research methods. The sample included 318 athletes recruited from Lithuanian universities. The participants completed the Youth Sport Value Questionnaire-2 (YSVQ-2; Lee et al., 2008) and the Moral Disengagement in Sport Scale-Short (MDSS-S; Boardley, Kavussanu, 2008).

Research results. The positive correlation between values in sport and negative correlation between moral values and moral disengagement in sport were established. Moral values were more important to females compared to males $(\mathrm{p}<0.01)$. Competence values were more important to international level athletes compared to the national level athletes $(\mathrm{p}<0.01)$. ANOVA indicated the differences of years of involvement in sport in dependence on moral values $(\mathrm{p}<0.05)$ and competence values $(\mathrm{p}<0.01)$.

Discussion and conclusions. Research established negative correlation between moral values and moral disengagement, but there were no correlations with status values. The study confirmed the hypothesis that female athletes' scores on moral values would be higher comparing to those of male, but there were no differences comparing moral disengagement in sport. Athletes of higher levels of competition (international level athletes) scored higher on competence values. Research supported the hypothesis that athletes' moral disengagement in sport would not differ across sport experience.
\end{abstract}

Keywords: sport, athletes' moral behavior, values in sport, moral disengagement in sport.

\section{INTRODUCTION}

$\mathrm{V}$ alues are defined as beliefs that certain goals or behaviors are more or less preferable to their alternatives (Rokeach, 1973). They serve the interests of individuals or groups, motivate action by giving it direction and intensity, provide standards by which behavior is evaluated, and are learned by individuals from the dominant values of their social groups and through their own experiences (Schwartz, 1994). Values can be organized in terms of system and structure. So, individuals and societies develop value systems in which values are ranked in importance (Rokeach, 1973). The evaluation of the role of values when behavioral decisions are made has received much attention from scientists. However, values have been underestimated in sport psychology (Lee et 
al., 2008). In sport, they might include not only criteria of success, such as winning or playing well, but also fair play, sportsmanship, friendship, and tolerance, which are concerned with the quality of interaction during the activity (Lee et al., 2000).

On the other hand, the attitudes towards sport and its values have been changing in modernizing society (Budreikaitè, Adaškevičienè, 2010). In this way traditional values in sport give way to consumer values (Genys, 2011). No coincidence, negative social behaviors, such as intentionally injuring an opposing player, cheating, and retaliating to a bad foul, are common in sport (Kavussanu, et al., 2006). In this context the relevant question is why people get engaged in negative behaviors. Athletes can be under pressure to engage in transgressive acts in order to justify the expectations of a coach, parents and even sponsors aiming at capturing the leadership position in the team, etc. As I. D. Boardley and M. Kavussanu (2007) suggest, "players are often evaluated based on the outcomes of their actions rather than the means through which they achieve them" (p. 609). Though some theories claim that the actions performed are linked to certain emotions (guilt or pride), which regulate future behavior anticipatorily, some individuals do not always act the way they should (Bandura, 1991). A. Bandura (1991) suggests that people are able to violate personal standards without self-sanction through the selective use of eight psychosocial maneuvers known as mechanisms of moral disengagement. These mechanisms allow individuals to transgress without experiencing negative affect, thereby decreasing constraint on future negative behavior. It should be noted that moral disengagement in sport context has received researchers' attention only during the last several years. It was established that moral disengagement had strong positive relationship with antisocial behavior towards both teammates and opponents (Boardley, Kavussanu, 2007, 2009) and with perceived value of toughness (Boardley, Kavussanu, 2010). It was also established that moral disengagement mediated relationship between controlled motivation and antisocial behavior toward teammates and opponents (Hodge, Lonsdale, 2011). Some recent studies have found that prosocial attitudes in sport are predicted positively by moral and competence values, whereas antisocial attitudes are predicted positively by status and negatively by moral values (Lee et al., 2008).
The data mentioned above induce further research aiming at two research targets. Firstly to examine whether there is a relationship between athletes' values and moral disengagement in sport. Secondly - to determine the manifestation of athletes' values and moral disengagement in sport and their dependence on athletes' gender, sports mastery and sports experience. In this study we extended previous research on moral behavior in sport by (1) examining athletes' values in sport and their relationship with moral disengagement, and (2) evaluating values and moral disengagement in sport by athletes' personal factors (gender, sports mastery and years of involvement in sport; and (3) our study involved university athletes as previous research often involved adolescents.

We hypothesized (H1) that moral and competence values would be negatively correlated with moral disengagement in sport, and status values would be positively correlated with moral disengagement in sport. Also we hypothesized (H2) that female athletes' scores on moral values would be higher than those of males, and scores on moral disengagement would be lower. Athletes' values but not moral disengagement in sport will differ across sports mastery (H3). Athletes' values and moral disengagement in sport will not differ across sports experience (H4).

\section{RESEARCH METHODS}

Research participants. The sample included 318 (237 male and 81 female) athletes recruited from Lithuanian universities. The condition of athletes' participation in our research was previous participation in a championship of the country, i. e. we tended to recruit athletes of higher sports mastery levels. For that reason we applied purposive sampling. Among the athletes who participated in this study, $52.5 \%$ noted that they were prizeholders in the national championship, $22.6 \%$ of them participated in the European Championship and $6.0 \%$ - in the World Championship. While analyzing the data athletes were divided into two groups by their sports mastery: National level (who participated only in the national championship) and International level (who participated in European or World Championship). Among the research participants, $68.5 \%$ played various ball games (basketball, volleyball, handball and football), $11.0 \%$ were in track and field events, and $21.5 \%$ were in other sports, mainly in individual sports. Years of involvement in their current sport ranged 
from $<1$ to $20(\mathrm{M}=9.43, \mathrm{SD}=3.38)$. While analyzing the data athletes were divided into three groups based on percentiles of their sport experience: $\geq 7$-year experience $(\mathrm{n}=89), 8-11$-years of sport experience $(\mathrm{n}=128)$, and $\leq 12$-year sport experience $(n=101)$.

Measures. The survey-style assessment questionnaire was used in this study and it contained three sections. The first requested the participants' gender, most recent sport, and years of involvement in that sport. The other sections assessed athletes' values and moral disengagement in sport. Each specific scale is described below.

The Youth Sport Values Questionnaire-2 (YSVQ-2; Lee et al., 2008). The 13-item questionnaire was headed What is important to me in sport and respondents were asked to "Please circle one of the numbers beside each item to show how important it is to you in your main sport." Responses produced were produced on a 7-point scale with the following response labels, each starting with the phrase "This idea is. "extremely important to me (5), very important to me (4), important to me (3), quite important to me (2), slightly important to me (1), not important to me (0), and the opposite of what I believe (-1). The YSVQ2 included three-factors (moral, competence, and status values) that were confirmed with the Lithuanian version of this questionnaire (Šukys, 2010). Alpha coefficients showed good-to-verygood levels of internal consistency and ranged from 0.89 to 0.79 .

The Moral Disengagement in Sport ScaleShort (MDSS-S; Boardley, Kavussanu, 2008). This eight item scale measured overall construct of sport moral disengagement. Items were rated on a 7-point scale anchored by strongly disagree (1) and strongly agree (7). Examples of items were "It is okay for players to lie to officials if it helps their team", "Shouting at an opponent is okay as long as it does not end in violent conduct", "A player should not be blamed for injuring an opponent if the coach reinforces such behavior". Although this scale was a unidimensional measure of sport moral disengagement, but it still had items measuring eight of the mechanisms of moral disengagement. However, in this study overall sport moral disengagement was of interest. Alpha coefficient for the overall scale was acceptable (0.70).

Statistical analysis. Statistical analysis of the data was performed using SPSS-13.0 package for Windows. After conducting descriptive statistical analysis, the internal consistency of the subscales was examined by conducting Cronbach's alpha analyses. Pearson's correlation coefficient was applied to identify correlations among the subscales. The statistical or null hypothesis (Ho) of equality of the mean $(\mathrm{M})$ between groups was tested using independent sample t-test and OneWay ANOVA. In all instances (comparing more than two groups) where the Ho was rejected, posthoc (Turkey test) was computed. In calculating the effect size $\left(\eta^{2}\right)$ for independent samples in a t-test the following formula was used: $\eta^{2}=\mathrm{t}^{2} /\left(\mathrm{t}^{2}+\mathrm{df}\right)$. For the analyses of variance the effect size was calculated: $\eta^{2}=$ Sum of squares between groups/ Total sum of squares. In interpreting effect size the guidance from J. Cohen (1988) was taken into account: $0.01-0.05$ very small effect, $0.06-0.14$ moderate effect and from 0.15 very large effect.

\section{RESEARCH RESULTS}

Descriptive statistics and correlations were computed using the entire sample and presented in Table 1. Athletes reported competence values the most, followed by moral and status values, respectively. Mean value for moral disengagement in sport shows that athletes more often tend to choose neutral position when evaluating eight statements related with behavior in sport. Significant correlations were $\mathrm{r}=0.54$ between moral and competence values, $r=0.62$ between competence and status values, and $r=0.33$ between status and moral values. As it was hypothesized, sport moral disengagement was negatively related with moral values, but there were no correlation with competence and status values.

Next we explored differences by athletes' gender, mastery, and years of involvement in sport (Tables 2, 3). Females' mean scores were significantly higher than those of males on moral values $(\mathrm{t}(316)=2.51, \mathrm{p}<0.01)$. Research results did not reveal statistically significant differences comparing overall moral disengagement in sport by gender. There were no differences comparing the evaluations of each eight statements by gender separately. The mean scores on competence values of international level athletes were significantly higher than those of athletes who participated in the national level contests $(\mathrm{t}(316)=2.50, \mathrm{p}<0.01)$. There were no statistically significant differences comparing both overall moral disengagement in sport scores and each statement separately. 

Table 1. Correlations,
reliability estimates,
and descriptive
statistics for the
YSVQ-2 and
MDSS-S $(\mathbf{n}=\mathbf{3 1 8})$
Note. ${ }^{* *}-\mathrm{p}<0.01$.
Alpha coefficients
are reported on the
diagonal.

\begin{tabular}{|l|c|c|c|c|}
\hline \multicolumn{1}{|c|}{ Variables } & $\mathbf{1}$ & $\mathbf{2}$ & $\mathbf{3}$ & $\mathbf{4}$ \\
\hline 1. Moral values & $(0.79)$ & & & \\
\hline 2. Competence values & $0.54 * *$ & $(0.89)$ & & \\
\hline 3. Status values & $0.33^{* *}$ & $0.62^{* *}$ & $(0.79)$ & \\
\hline 4. Moral disengagement & $-0.24 * *$ & -0.02 & 0.06 & $(0.70)$ \\
\hline Mean & 3.78 & 4.06 & 3.43 & 3.51 \\
\hline Standard deviation & 0.83 & 1.04 & 1.17 & 1.08 \\
\hline
\end{tabular}

Table 2. Means, SD, and effect size of youth sport values and moral disengagement in sport by athletes' gender and mastership $(\mathrm{n}=318)$

Note. $* *$ - statistically significant difference $(\mathrm{p}<0.01)$.

\begin{tabular}{|c|c|c|c|c|c|c|c|c|c|c|}
\hline \multirow{3}{*}{ Variables } & \multicolumn{5}{|c|}{ Gender } & \multicolumn{5}{|c|}{ Mastership } \\
\hline & \multicolumn{2}{|c|}{ Female $(n=81)$} & \multicolumn{3}{|c|}{ Male $(n=237)$} & \multicolumn{2}{|c|}{$\begin{array}{l}\text { National level } \\
\quad(\mathrm{n}=236)\end{array}$} & \multicolumn{3}{|c|}{$\begin{array}{l}\text { International level } \\
\quad(\mathbf{n}=\mathbf{8 2})\end{array}$} \\
\hline & M & SD & M & SD & $h^{2}$ & $\mathbf{M}$ & SD & $\mathbf{M}$ & SD & $\mathbf{h}^{2}$ \\
\hline Moral values & 3.98 & 0.72 & 3.71 & 0.86 & $\begin{array}{c}0.02 \\
* *\end{array}$ & 3.78 & 0.83 & 3.80 & 0.83 & 0.001 \\
\hline $\begin{array}{l}\text { Competence } \\
\text { values }\end{array}$ & 4.04 & 0.99 & 4.06 & 1.06 & 0.001 & 3.97 & 1.02 & 4.30 & 1.05 & $\begin{array}{c}0.02 \\
* *\end{array}$ \\
\hline Status values & 3.26 & 1.24 & 3.50 & 1.14 & 0.01 & 3.39 & 1.21 & 3.56 & 1.02 & 0.004 \\
\hline $\begin{array}{l}\text { Moral } \\
\text { disengagement }\end{array}$ & 3.50 & 1.07 & 3.51 & 1.10 & 0.001 & 3.45 & 1.06 & 3.65 & 1.16 & 0.007 \\
\hline
\end{tabular}

Table 3. Means, SD, and effect size of youth sport values and moral disengagement in sport by the year of involvement in sport $(\mathbf{n}=318)$

Note. $*$ - statistically significant difference $(\mathrm{p}<0.05) . * *$ statistically significant difference $(p<0.01)$.

\begin{tabular}{|c|c|c|c|c|c|c|c|}
\hline \multirow{3}{*}{ Variables } & \multicolumn{7}{|c|}{ Years of involvement in sport } \\
\hline & \multicolumn{2}{|c|}{$\begin{array}{c}\geq 7 \text {-year experience } \\
(\mathrm{n}=89)\end{array}$} & \multicolumn{2}{|c|}{$\begin{array}{c}\text { 8-11-year experience } \\
(\mathrm{n}=128)\end{array}$} & \multicolumn{3}{|c|}{$\leq 12$-year experience $(n=101)$} \\
\hline & $\mathbf{M}$ & SD & $\mathbf{M}$ & SD & $\mathbf{M}$ & SD & $\mathbf{h}^{2}$ \\
\hline Moral values & 3.68 & 0.96 & 3.94 & 0.69 & 3.71 & 0.77 & $0.02 *$ \\
\hline Competence values & 3.85 & 1.23 & 4.26 & 0.80 & 4.02 & 1.01 & $0.03 * *$ \\
\hline Status values & 3.24 & 1.28 & 3.54 & 1.12 & 3.45 & 1.14 & 0.01 \\
\hline Moral disengagement & 3.36 & 1.06 & 3.54 & 1.11 & 3.58 & 1.09 & 0.001 \\
\hline
\end{tabular}

ANOVA indicated the differences of years of involvement in sport in dependence on moral values $(\mathrm{F}(2,316)=3.60, \mathrm{p}<0.05)$. The Turkey test found that the means for $\geq 7$-year involvement in sport, and eight to 11 years of involvement in sport were statistically significantly different from each other ( $p<0.05)$, and that there were no other statistically significant differences comparing the mean values between other groups of athletes. ANOVA indicated the differences in the years of involvement in sport on competence values, respectively $(\mathrm{F}(2,316)=4.55, \mathrm{p}<0.01)$. The Turkey test found that the means for $\geq 7$-year involvement in sport and eight to 11 years of involvement in sport were statistically significantly different from each other $(\mathrm{p}<0.01)$, and that there were no other statistically significant differences comparing the mean values between other groups of athletes.

\section{DISCUSSION}

Our research purposes were, first, to examine the relationship between university athletes' values and moral disengagement in sport. It was hypothesized that moral and competence values would be negatively correlated with moral disengagement in sport. Research results partly confirmed this hypothesis as we established a negative correlation between moral values and moral disengagement, but there were no correlation with competence 
values. It should be noted that our hypothesis was based on other studies which indicated that moral disengagement in sport correlated with antisocial behavior (Boardley, Kavussanu, 2007, 2009) and antisocial attitudes correlated with status values (Lee et al., 2008). It is worth noting that this study did not reveal positive relations between status values and moral disengagement in sport. However, in previous studies no relation between status values and antisocial behavior of students engaged in sports was established either (Šukys, 2010). But moral disengagement in sport could be as mediator when examine relationship between athletes values and actual behavior.

The second purpose of our research was to examine the manifestation of athletes' values and moral disengagement in sport in dependence of gender, sports mastery and years of experience in sports. Our research only partly confirmed the hypothesis that female athletes' scores on moral values would be higher than those of male, and scores on moral disengagement were lower, on the contrary. Though moral values were more important to females engaged in sports compared to males, but the established effect of size was very low. Besides, female athletes' scores on moral disengagement in sport were not lower than those of male. This does not confirm the results of other studies which found that men displayed higher levels of moral disengagement than women (Boardley, Kavussaanu, 2007). Our data also indirectly contradicted to the findings of other research that sport moral maturity differed significantly across gender, with female athletes having higher moral reasoning scores than male athletes (Miller et al., 2004). Those differences can be explained by the fact that sport is traditionally male domain and stereotypic expectations of masculinity are believed to influence male sport behavior (Greendorfer, 1993; Schissel, 2000). Besides, masculinity is related with perceived value of toughness, especially in some contact sports (Shissel, 2000; Burgess et al., 2003). Some recent studies indicated that perceived value of toughness had indirect positive effects on antisocial behavior toward opponents and teammates (Boardley, Kavussanu, 2010). However, the latter researchers note that athletes from different sports display different levels of morality, e. g. in moral disengagement is higher in soccer than in basketball, hockey, and netball (Boardley,
Kavussanu, 2007). More than one third of our research sample were students playing basketball, thus we did not compare our findings according to the branches of sports. Besides, the number of females in our study was markedly less compared to males. Thus, further research examining moral disengagement in sport should focus on gender in the comparisons of athletes in different branches of sports.

It was hypothesized that athletes' values but not moral disengagement in sport would differ across sports mastery. Our findings confirmed this hypothesis only partly because athletes of higher levels of competition (international level athletes) scored higher on competence values. It means that in sport for them is much more important to become a better athlete, use own personal skills well, set own targets, and improve their performance. It should be noted that there were differences in the evaluations of different competences, but the effect size was very low. On the other hand, it was confirmed that athletes' moral disengagement in sport would not differ across sports mastery.

Our research partly confirmed the hypothesis that athletes values in sport would not differ across sport experience. According to the data of our research, both moral and competence values were equally important to athletes with both the least and the greatest sports experience. However, 8-11-year-old athletes produced different results, as the values mentioned above were more important for them. We suggest that when athletes gain more experience in their sports, moral and competence values become more important to them, but later their significance decreases. Research supports the hypothesis that athletes' moral disengagement in sport would not differ across sport experience. Such presumption was based on previous research that sport experiences are not associated with antisocial behavior (Boardley, Kavussanu, 2010). Nevertheless, some recent studies suggested that sport experience positively predicted antisocial behavior in sport (Sagar et al., 2010). In the context of our research we should note that the research participants were adult athletes. We suppose that our hypothesis might not have been confirmed in the study of children as other research has indicated that sport experience factor could be more important examining children's moral behavior in sport (Lee et al., 2007). 


\section{CONCLUSION AND PERSPECTIVES}

Our research established negative correlation between moral values and moral disengagement, but there were no correlations with competence and status values. The study only partly confirmed the hypothesis that female athletes' scores on moral values would be higher than those of male. However, we did not confirm the supposition that female athletes' scores on moral disengagement in sport would be lower than those of male. Athletes of higher levels of competition (international level athletes) scored higher on competence values. Research supported the hypothesis that athletes' moral disengagement in sport would not differ across sport experience, but did not confirm the supposition about differences in values in sport.

Although previous research examined the relationship between moral disengagement and antisocial behavior in sport (Boardley, Kavussanu, 2007, 2009; Hodge, Lansdale, 2011), the role of values was underestimated. Further research should verify the hypothesis about moral disengagement in sport being as mediator when examining the relationship between athletes' values and actual behavior.

\section{REFERENCES}

Bandura, A. (1991). Social cognitive theory of moral thought and action. In W. M. Kurtines, J. L. Gewirtz (Eds.), Handbook of Moral Behavior and Development: Theory, Research, and Applications (Vol. 1, pp. 45-103). Hillsdale, NJ: Lawrence Erlbaum Associates.

Boardley, I. D., Kavussanu, M. (2007). Development and validation of the moral disengagement in sport scale. Journal of Sport \& Exercise Psychology, 29, 608-628.

Boardley, I. D., Kavussanu, M. (2010). Effects of goal orientation and perceived value of toughness on antisocial behavior: The mediating role of moral disengagement. Journal of Sport \& Exercise Psychology, 32 (2), 176-192.

Boardley, I. D., Kavussanu, M. (2009). The influence of social variables and moral disengagement on prosocial and antisocial behaviors in field hockey and netball. Journal of Sports Sciences, 27 (8), 843-854.

Boardley, I. D., Kavussanu, M. (2008). The moral disengagement in sport scale - short. Journal of Sports Sciences, 26 (14), 1507-1517.

Budreikaitė, A., Adaškevičienė, E. (2010). Sportuojančiu ir nesportuojančių paauglių požiūris i vertybes ir jų prasmès suvokimą. Ugdymas. Kūno kultūra. Sportas, 1 (76), 13-20.

Burgess, I., Edwards, A., Skinner, J. (2003). Football culture in an Australian school setting: The construction of masculine identity. Sport, Education \& Society, 8 (2), 199-212.

Cohen, J. (1988). Statistical Power Analysis for the Behavioral Sciences (2nd ed.). Hillsdale, NJ: Lawrence Earlbaun Associales.

Genys, D. (2011). Nuo vertybinio idealizmo iki pragmatinès komercijos? Olimpinès vertybès ir jų kaita. Sporto mokslas, 1 (63), 5-12.

Greendorfer, S. (1993). Gender role stereotypes and early childhood socialization. In G. L. Cohen (Ed.), Women in Sport: Issues and Controversies (pp. 3-14). Newbery Park, CA: Sage Publications.

Hodge, K., Lonsdale, Ch. (2011). Prosocial and antisocial behavior in sport: The role of coaching style, autonomous vs. controlled motivation, and moral disengagement. Journal of Sport \& Exercise Psychology, 33 (4), 527-547.

Kavussanu, M., Seal, A., Phillips, D. (2006). Observed prosocial and antisocial behaviors in male soccer teams: Age differences across adolescence and the role of motivational variables. Journal of Applied Sport Psychology, 18 (4), 326-344.

Lee, M. J., Whitehead, J., Balchin, N. (2000). The measurement of values in youth sport: Development of the Youth Sport Values Questionnaire. Journal of Sport á Exercise Psychology, 22, 307-326.

Lee, M. J., Whitehead, J., Ntoumanis, N. (2007). Development of the attitudes to moral decision-making in youth sport questionnaire (AMDYSQ). Psychology of Sport \& Exercise, 8 (3), 369-392.

Lee, M. J., Whitehead, J., Ntoumanis, N., Hatzigeorgiadis, A. (2008). Relationships among values, achievement orientations, and attitudes in youth sport. Journal of Sport and Exercise Psychology, 30 (5), 588-610.

Miller, B. W., Roberts, G. C., Ommundsen, Y. (2004). Effect of motivational climate on sportspersonship among competitive youth male and female football players. Scandinavian Journal of Medicine and Science in Sport, 14 (3), 193-202.

Rokeach, M. (1973). The Nature of Human Values. New York: The Free Press.

Sagar, S. S., Boardley, I. D., Kavussanu, M. (2010). Fear of failure and student athletes' interpersonal antisocial behaviour in education and sport. British Journal of Educational Psychology, 81 (3), 391-408.

Schissel, B. (2000). Boys against girls. The structural and interpersonal dimensions of violent patriarchal culture in the lives of young men. Violence Against Women, 6 (9), 960-987.

Schwartz, S. H. (1994). Are there universal aspects in the structure and content of human values? The Journal of Social Issues, 50 (4), 19-45.

Šukys, S. (2010). Prosocialaus ir antisocialaus elgesio skalès bei jaunimo vertybių sportinèje veikloje klausimyno adaptavimas lietuviams. Ugdymas. Kūno kultūra. Sportas, 3 (78), 97-104. 


\title{
VERTYBIU BEI MORALINIO PATEISINIMO SPORTINĖJE VEIKLOJE TARPUSAVIO RYŠIAI IR RAIŠKA SPORTININKŲ LYTIES, MEISTRIŠKUMO IR SPORTINĖS PATIRTIES POŽIŪRIU
}

\author{
Saulius Šukys ${ }^{1}$, Aušra Janina Jansoniene் $\dot{2}^{2}$ \\ Lietuvos kūno kultūros akademija', Kaunas, Lietuva \\ Kauno technologijos universitetas ${ }^{2}$, Kaunas, Lietuva
}

\begin{abstract}
SANTRAUKA
Tyrimo pagrindimas ir hipoteze. Tyrimu buvo gilinamasi $\mathfrak{i}$ universitetu studentu vertybes ir moralinio pateisinimo sportinejje veikloje problematiką. Keliama hipotezè, kad moralinès ir gebejimų ugdymo vertybès neigiamai koreliuoja su moraliniu pateisinimu sportinèje veikloje. Taip pat tikimasi, kad sportuojančiu studentu vertybès sportinèje veikloje skirsis pagal lytị ir sportini meistriškumą.

Tikslas - išsiaiškinti sportuojančiu studentu vertybių ir moralinio pateisinimo sportinėje veikloje tarpusavio ryšius ir raišką lyties, sportinio meistriškumo ir sportinès patirties požiūriu.

Metodai. Tiriamuju kontingentą sudare 318 sportuojančių studentų parinktų iš įvairių Lietuvos universitetų. Tiriant studentus naudoti: Jaunimo vertybiu sportinèje veikloje klausimynas-2 (YSVQ-2; Lee et al., 2008) ir Moralinio pateisinimo sportinejje veikloje trumpoji skalè (MDSS-S; Boardley, Kavussanu, 2008).

Rezultatai. Nustatyta teigiama koreliacija tarp atskirų vertybių grupių, o neigiamas ryšys - tarp moraliniu vertybiu ir moralinio pateisinimo sportineje veikloje. Sportuojančioms merginoms, lyginant jas su vaikinais, moralinės vertybės sportinèje veikloje svarbesnès $(\mathrm{p}<0.01)$. Didesnio meistriškumo sportininkams sportinèje veikloje svarbesnès gebėjimų ugdymo vertybės $(\mathrm{p}<0.01)$. Moraliniu $(\mathrm{p}<0.05)$ ir gebėjimų ugdymo $(\mathrm{p}<0.01)$ vertybių reikšmingumas sportinèje veikloje skiriasi priklausomai nuo sportuojančių studentų sportinès patirties.

Aptarimas ir išvados. Tyrimas atskleidè: tarp moralinių vertybiu ir moralinio pateisinimo sportinèje veikloje egzistuoja neigiamas ryšys. Nepasitvirtino prielaida, kad tarp statuso vertybiu ir moralinio pateisinimo sportinèje veikloje turi būti teigiamas ryšys. Sportuojančioms merginoms sportinėje veikloje svarbesnès moralinės vertybės, tačiau nenustatytas skirtumas vertinant moralinio pateisinimo sportinèje veikloje rezultatus pagal lyti. Skirtingo meistriškumo sportuojančiu studentų vertybių sistema sportinèje veikloje skiriasi. Pasitvirtino hipotezè, kad moralinio pateisinimo sportineje veikloje duomenys skirtingos sportinès patirties grupėse nesiskiria.
\end{abstract}

Raktažodžiai: sportinė veikla, moralinis elgesys sportinėje veikloje, vertybès sportinėje veikloje, moralinis pateisinimas.

Gauta 2012 m. sausio 9 d.

Received on January 9, 2012

Priimta 2012 m. kovo $13 \mathrm{~d}$.

Accepted on March 13, 2012

Corresponding author Saulius Šukys

Lithuanian Academy of Physical Education

Sporto str. 6, LT-44221 Kaunas

Lithuania

Tel +370 37302638

E-mails.sukys@1kka.lt 